\title{
Do Political Disruptions Affect Supply Chain Performance? A Qualitative Case Study of the Textile Supply Chain in Pakistan
}

\author{
Author(s): Muhammad Asif, Prem Chhetri, Rajiv Padhye
}

Source: Journal of International Logistics and Trade 2019; 17(3):77-88

Published by: Jungseok Research Institute of International Logistics and Trade, Inha University

DOI: https://doi.org/10.24006/jilt.2019.17.3.077

The Journal of International Logistics and Trade is an official journal published by Jungseok Research Institute of International Logistics and Trade, Inha University, Korea. JILT welcomes manuscripts that advance the practice and science of logistics, trade, and other related fields.

Frequency: Quarterly (March, June, September, December)

Stable URL: https://www.ejilt.org

The Jungseok Research Institute of International Logistics and Trade is a specialized academic research institute representing Inha University and the Inha Foundation in Korea. The institute aims to become a representative institute in Northeast Asia in the research of logistics and trade.

Stable URL: https://jrieng.inha.ac.kr

(C) Copyright. Jungseok Research Institute of International Logistics and Trade.

This is an Open-Access article distributed under the terms of the Creative Commons Attribution NonCommercial License (http://creativecommons.org/licenses/by-nc/4.0/) which permits unrestricted noncommercial use, distribution, and reproduction in any medium, provided the original work is properly cited 


\title{
Journal of
}

\section{International Logistics and Trade}

\section{Do Political Disruptions Affect Supply Chain Performance? A Qualitative Case Study of the Textile Supply Chain in Pakistan}

\author{
Muhammad Asif, Prem Chhetri*, Rajiv Padhye \\ Department of Business IT and Logistics, RMIT University, Australia
}

\begin{abstract}
ARTICLE INFO
Article history:

Received 19 April 2019

Revision received 19 June 2019

Accepted 27 June 2019

Keywords:

Political disruption

Supply chain performance

Supply chain disruption

Textile industry
\end{abstract}

\begin{abstract}
This paper explores the interaction and impact of political disruptions on textile supply chain performance in Pakistan. A qualitative approach is adopted to explore the linkages and relationships between political disruptions and supply chain disruptions and performance. Semi-structured interviews were conducted at 25 different textile manufacturing firms. This study confirmed the prevalence of severe and variegated impacts of political disruptions on the textile supply chain. Supply chain disruption is found to be a key mediating factor that directly and indirectly affect supply chain performance through an increased production and delivery lead-time, transportation delays, interruptions of raw material supplies to plants and distributors and the restricted access to workplaces for suppliers and workers. The linkages are represented through vicious circles that illustrate the interactions and inter-relationships between disrupted supply chain and performance. This study provides empirical evidence to help government to formulate pertinent labour laws and industrial policy to mitigate political disruptions and minimise deleterious effects of supply chain disruption on production and distribution networks whilst respecting and protecting the democratic rights of people.
\end{abstract}

(C) 2019 Jungseok Research Institute of International Logistics and Trade All rights reserved.

\section{Introduction}

Supply chains are increasingly becoming global, complex and competitive to deal with the increased volatility, ubiquity and Just-in-time customer demand (Tang, 2011). Globalization also means increased vulnerability of supply chains to disruptive events including political disruptions and social disorder. Political disruptions are reflected in the form of riots and street demonstrations, military coup and revolution and politically motivated violence and terrorism (Alex and Jongman, 2005). Recent studies (Bashir et al., 2013; Butkiewicz and Yanıkkaya, 2005; Fosu, 2003; Aisen and Veiga, 2013; Musa, 2012) have shown the negative impacts of political disruptions on supply chain performance, yet a deeper understanding of these relationships and interactions is still needed to provide clarity and transparency for effective policy making and governance.

An increased globalization and the consequent decentralization of production systems further necessitates an improvement in our understanding of these interwoven relationships between political disruptions and supply chains. In recent years, there have been a few attempts that have examined the impact of supply chain disruptions on supply chain performance (Wang et al., 2017; Gandhi et al., 2017; Dweekat et al., 2017). Yet, the political disruption and the resultant impacts on supply chain performance is insufficiently theorized and empirically validated. It is argued that the development of a stronger theoretical framework would unfold the nexus between political disruptions and supply chain

\footnotetext{
* Corresponding author: Department of Business IT and Logistics, RMIT University, 124 La Trobe St, Melbourne, Australia; Email: prem.chhetri@rmit.edu.au
} 
performance to help transform organizational culture, attitude and tolerance, and inject agility to production system to adapt to increased demand volatility and uncertainty. Political instability, socio-institutional failures, national and international insecurity are the most crucial challenges for businesses to operate the textile industry in an efficient and sustainable way (Langley, 2011).

The textile industry is paramount to the success of Pakistan's economic development (Khan and Khan, 2010). Pakistan has retained a significant share of world textile and clothing exports. Pakistan is the 8th largest exporter of textile products in Asia. This sector contributes $9.5 \%$ to the GDP and provides employment to about 15 million people or roughly $30 \%$ of the 49 million work force in the country (Tahir et al., 2014). In addition, Pakistan is the 4th largest producer of cotton with the third largest spinning capacity in Asia after China and India and contributes 5\% to the global spinning capacity (TRIBUNE News, 2013).

Pakistan has a history of political disruptions (Khan and Saqib, 2011). These disruptions have significantly slowed down the economic growth and thwarted the future of democracy in Pakistan. The long-term effects of political disruptions include an exodus of skilled and trained workers to overseas labor markets and labor and skills shortages in critical industries. In addition, the textile industry faces huge shortages in the supply of raw materials, and constantly threatened by transportation bottlenecks and production disruptions (The Express TRIBUNE, 2004). This economic and political instability discourages international buyers intended to invest in Pakistan to explore new business opportunities in untapped markets. The urgency of this issue is also acknowledged by the World Bank, which reports that Pakistan has lost about 2.1 percent of the GDP during sit-ins organized by political parties (The World Bank, 2014). This paper therefore adopts a case study approach to explore the linkages and relationships between political disruptions and supply chain disruptions and performance in Pakistan.

The paper is structured as follows: Section 2 reviews the key studies in the field of supply chain management, followed by the methodology in Section 3. Section 4 presents the thematic analysis and synthesis of the results of the qualitative data gathered via semi-structured interviews. The paper concludes with a summary of findings and an outline of limitations of the methodology presented, along with suggestions for future research.

\section{Literature review}

Political disruptions are politically motivated activities, which are irregular, typically violent and directed against the governing regime or its policies (Kobrin, 1977). These events or activities are often outside of the bound of social expectations of a given society. Williams (2012) defines political disruption as "a situation in which conditions and mechanisms of governance and rule are challenged as to their political legitimacy by elements operating from outside the normal operations of the political system". Different forms of political disruptions include political violence, terrorism, military coups, riot and street demonstration, revolution, assassination and guerrilla warfare (Bashir et al., 2013; Kobrin, 1977). The impacts of these politically driven disruptive events on the efficiency and performance of supply chains are severe and economically irreparable.

Pakistan's political, institutional and democratic systems have been relatively unstable (DAWN, 2016) and slightly weakened in the post-independent era. Pakistan changed seven Prime Ministers from 1947 to 1958 (GEO news, 2016). This was partly due to the political system, which allowed the military to intervene in situation of political crisis (Jalal, 2014). According to the World Bank Cross-Country Data (2015), political stability in Pakistan has continually decreased during the years from 1998 to 2013 in figure 1. The graph in Figure 1 shows that, political stability has decreased from 1996 to 2002, improved after 2004 and declined in later years. This gradual decrease in political stability has had a considerable impact on Pakistan's economy, social conditions and institutional culture. Political instability has created situations in which industries are neither able to improve their supply chain performance nor harness the growth potential in a globalized world economy (Nawaz, 2015). The composite manufacturing operations of the textile supply chain have made the textile industry more susceptible in the wake of the country's political disruptions (Khan and Khan, 2010).

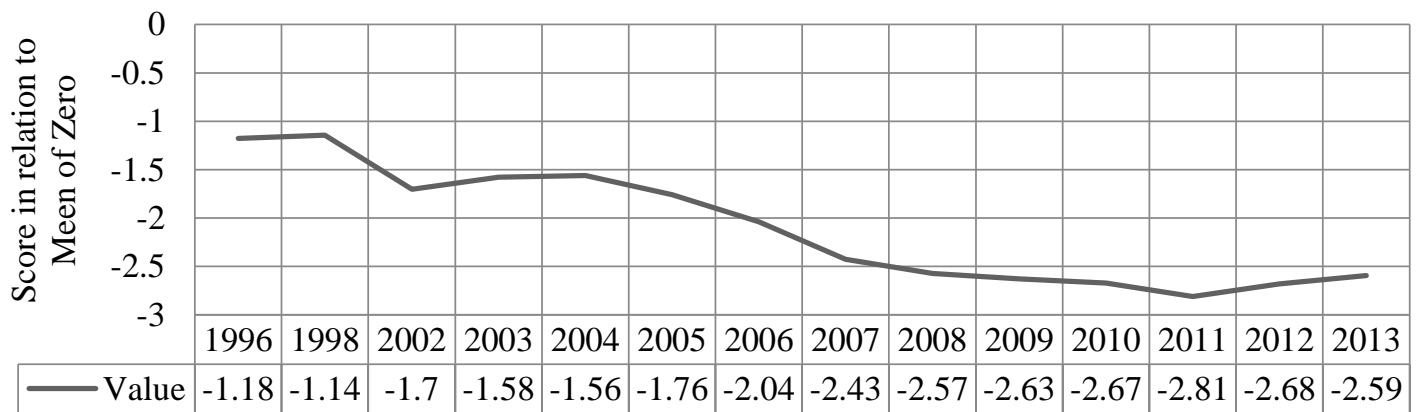

Figure 1. Political stability from 1996 to 2013 in Pakistan (World Bank cross-country data 2015) 
Terrorist incidents in Pakistan 2003- March 20, 2019

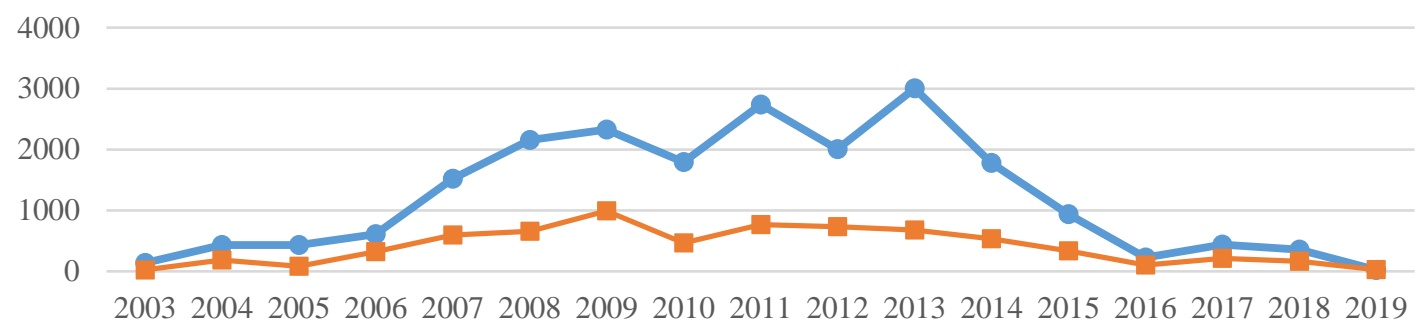

- Civilians $\quad-$ Security Forces Personnel

Figure 2. Terrorism incidents in Pakistan 2003- March 20, 2019 (SATP, 2019)

In Pakistan, political, socio-institutional, and national and international security have become the most crucial challenge for the efficiency of textile supply chain (Langley Jr., 2012). Political violence, terrorism, military coups and street demonstrations are the major forms of political disruptions, which have significant effect on supply chain performance in Pakistan. Political violence and terrorism are not only responsible for human causalities but also a key factor for infrastructure disinvestment and withdrawal of FDI in Pakistan (Khan, 2014). Figure 2 shows the human causalities caused by terrorism from 2003 to 2015 in Pakistan.

Political violence is also one of the major reasons causing political instability in Pakistan. World Bank Cross-Country Data (2015) ranked Pakistan 7th most political violent country in the world in figure 3. Currently, Pakistan's textile supply chain is more vulnerable to disruptions due to its supply chain complexity and unexpected consequences of political instability. Pakistan supply chain is ranked at the bottom 3, which how vulnerable it is to supply chain disruptions (BCI Company, 2015). Natural and manmade disasters are common in Pakistan, which affect the flow of products and information from farms to factories and then to demand nodes. Disruptions in the supply chain could occur in any node or link (Harvard Business Review, 2014) but their impact are often severe at decoupling points.

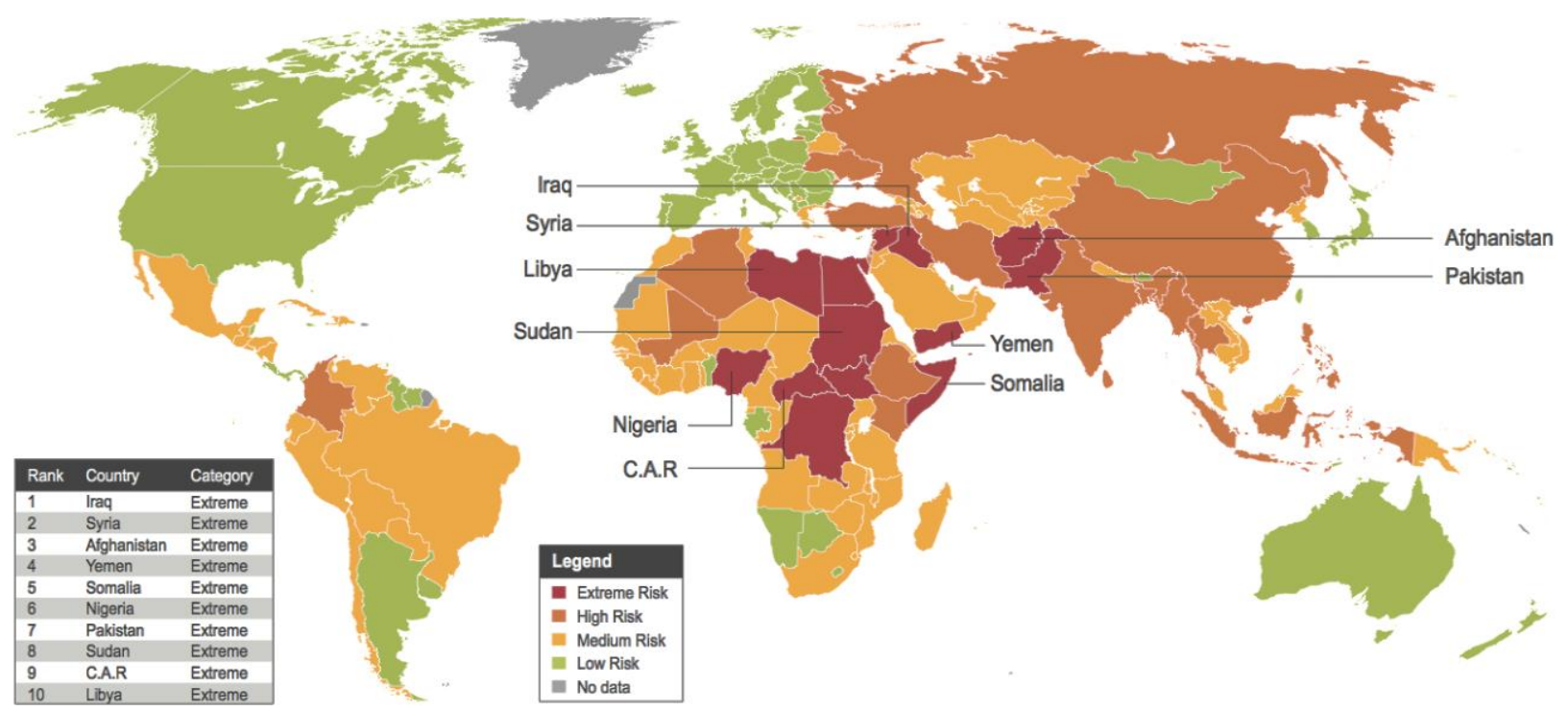

Figure 3. Political violence index (Business Insider Australia, 2014)

Textile supply chain in the globalized marketplace has become more complex than ever before. This increased complexity is attributed to globalizations, outsourcing and spatial fragmentation of production or consumption systems. Arguably, global supply chains are becoming susceptible to unplanned and undesirable disruptions (Koprulu and Albayrakoglu, 2007). A supply chain disruption is "unplanned events that may occur in the supply chain which might affect the normal or expected flow of materials and components" (Svensson, 2002). A supply chain disruption is an event that could take place at any point in the supply chain with the capacity to disrupt the normal flow of goods and materials within a supply chain (Craighead et al., 2007; Melnyk et al., 2009).

Considering a supply chain as a network, a disruption can occur in any production node or distribution link of the chain. The source of disruption however could be located inside or outside the chain (Brenner, 2015; Schoenherr et al., 2008). An interruption in the expected flow of materials from suppliers is not simply due to a service failure but also resulted from a natural or human-made disaster or a political disruption within the region (Beamon, 1999). The impact of 
the disruption can be immediate or gradual on the wider supply chain (Blackhurst et al., 2005). Also, a disruption may have a long-term impact on supply chain efficiency and economic performance. For example, if a customer relationship or company reputation is damaged, the impact of disruption can be long lasting and hard to recover (Sheffi, 2005). The performance of a supply chain is generally analysed in terms of service quality levels (e.g. punctuality, the number of late orders; delivery lead time), financial aspects (e.g. profit or operational cost) or a combination of both (Beamon, 1999). These performance indicators are affected by both internal and external processes and systems, which can be politically driven. Furthermore, textile manufacturers are becoming more conscious of the impacts of supply chain disruptions in relation to a company's reputation, earnings, profit values, image and ability to provide better returns to shareholders (Casey and Pasztor, 2007). The expected exposure of a supply chain to the potential risk of a disruption is measured by the possibility of the disruption and the impact of that disruption should it take place (Zsidisin et al., 2005).

Political disruptions are essentially a collective representation of resistance to the government regime and its rules, structures and policies that regulate, conduct and govern structure and institutional behavior. Political instability and unrest are equally vital in creating disruptions in production and distribution operations within a firm or across supply chains. For example, a labor strike is the collective resistance to the current management regimes, which dictate the appropriateness of working conditions, norms and guidelines for workers and production systems. Labor strike can cripple the production systems and exerts wider impact on the efficiency and effectiveness of supply chains. The reproduction of these rules and guidelines operating internally and externally requires a systematic implementation of change management. Civil resistance and demand for improvement through the process of collective bargaining or individual choice are the key sources of political disruptions. The political economy of the textile supply chains, which provides the basis for exploring the process of constant reproduction of rules, guidelines, and regulations is inadequately developed in the context of developing countries such as Pakistan. This study proposes a conceptual framework, which explores the complex and interwoven relationships between political disruption and supply chain disruption and the resultant impact on textile supply chain performance in Pakistan in figure 4. The relationship is theorized on the premise that there are direct and indirect impacts of political disruptions on supply chain performance.

The role and importance of political disruptions in the efficient management of supply chain are widely recognised (Aisen and Veiga, 2013; Awokuse and Gempesaw II, 2005; Fosu, 2003; Feng, 2001). Yet, there are only few studies (Lee and Lin, 2016; Lee, 2016; New Era Publication Corporation, 2015; Wilson and Barbat, 2015; Davarzani et al., 2015) that have explored the impact of political instability on supply chain. The lacking is attributed to the need to adopt interdisciplinary approach to develop a deeper understanding of the institutional structures and political processes that underpin the efficiency of production and distribution systems of the textile industry. There are hardly any empirical studies in supply chain management that explored the political aspects of supply chain performance. In addition, the political sensitivity of the subject, in the context of Pakistan in particular, also thwarted the effort to explore the political economy of production and operation management systems. This study aims to achieve this by linking internal production systems with the external political environment. This study therefore addresses the gap in the extant literature by framing complex questions that require connecting production and distribution systems with political processes and institutional structures.

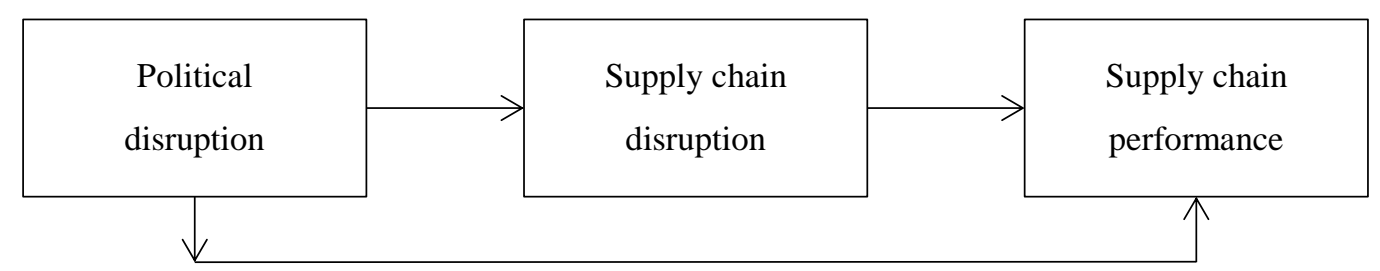

Figure 4. A conceptual framework for linking political disruptions with supply chain performance

\section{Research methodology}

In this study, a qualitative approach was adopted to explore the linkages and relationships between political instability and supply chain disruptions and performance. Semi-structured interviews were conducted to collect data on the perception of political disruptions and their impact on supply chain performance. Semi-structured interviews allowed changing the question order according to the types of participants to differentiate the variegated perceptions of groups such as political interest groups or supply chain managers (Saunders and Lewis, 2011). At first, interview questions were developed on the basis of key questions to reflect the theoretical framework and adjusted to the gaps identified in previous studies (Lorentz and Hilmola, 2012; Hendricks and Singhal, 2012; Hopp et al., 2012; Musa, 2012). This method was adopted as it allows for minimal non-response and maintain the quality of collected data. Face-to-face interviews were organized to collect data from major textile organizations, supply chain service providers and local community groups in Pakistan. The participants were requested to share their opinions on a set of broad interview questions and elicit their views on the nexus between political disruptions and supply chain performance. 
Questions were designed as open-endedly as possible so that participants could understand and respond accordingly. It was permissible to interview in the local language (i.e. Urdu) because some of participants might have difficulty expressing their opinions and viewpoints on the subject matter. The reason for allowing participants to use their local language was to capture their maximum response. All interviews were planned, and the participants asked to read through the questions before the interview commenced. All participants were briefed about the style and requirements of the interviews. Given the privacy and sensitiveness of the topic, few interviews were not recorded.

In this study, a purposeful sampling was used to collect the rich information to answer the research questions (Patton, 2002). Several criteria were employed to select the sample, including the respondent's position, knowledge of the industry and the length of service within the industry. It was premised that participants' strong organizational capabilities and their knowledge about textile supply chain industry would yield reliable and valid results. Various textile manufacturing organizations were contacted with the aim to attain sufficient sample to gather in-depth understanding of a range of issues related to political disruptions and supply chain performance. Twenty-five participants were interviewed. Ten participants were chosen from the textile industry, five from third party logistics providers, five from political groups, three from influence groups and two from community groups. All participants were of equal important and all viewpoints were considered.

\section{Results and interpretation}

The results and findings from the interview data are interpreted using the subjectively extracted broader themes, which reflect the relationships between political disruptions and supply chain performance. The key themes include: i) a multiple representation of political disruptions; ii) relationship between political disruptions with supply chain disruptions; and iii) and impact of political disruptions on supply chain performance. The results are then synthesized to provide a higherorder summary of the complex interactions and interdependencies of politically driven disruptive events on supply chain performance.

\subsection{Compounded and cascading impacts of political disruptions}

Political disruption is perceived differently by people. The views held by participants seem to have multiple perceptions and different interpretation of the meaning of political disruption. These variegated perceptions have significant effect on the way people view the impact of political disruptions on supply chain performance. The perceptions of interviewees indicate the growing complexity of political disruptions with constant change in the government. It was found that supply chains have become more vulnerable to disruptions due to the systemic problems associated with political instability in Pakistan. Political disruptions are considered as one of the main causes of supply chain disruptions, which directly or indirectly linked to labor strikes, raw material quality problems, transportations, production delay, delivery lead time delay and reduced supply chain performance. It is linked to the law and order situation which is highlighted by the Manager of a textile spinning manufacturer firm; "Political disruption we can say that the condition under which government fails to maintain law and order situation that impacts on our production and product delivery operations." (AAH).

The textile industry is important to macro-economy in two respects: foreign exchange earnings and employment creation. In Pakistan, textile is one of the biggest sectors offering employment to almost 40 per cent to the industrial labor force and helps textile exporters to sustain 60 per cent share in the nationwide export (Parkistan \& Gulf Economist, 2018). Textile garments manufacturers required the stable political environment to maintain and optimize their supply and demand as well as improve the ability to compete with other competitors. Most political disruptions in Pakistan emanating from the premature dismissals of governments, assassinations of party leaders, frequent government changes and martial laws. Such political conditions seriously harm the implementation or continuation of government policies. Political disruptions tend to mainly affect garment manufacturers because most of the garment products are manufactured for highly volatile and competitive European markets. A small change in the supply chain could lead to cascading effects of the entire supply chain. It is harder to mitigate supply risk in a global marketplace with multiple players willing to take on risk. Political stability is the key driver of economic growth and international trade. One textile exporter defined political disruption to include: "All actions or events against government regime or government policies..." (MT).

Political disruptions are not isolated events. They are part of the political processes and institutional structures within which they germinate and grow. Political disruptions however are linked to supply chain processes and are inseparable part of the production and distribution systems. Political disruptions are intertwined with supply chain disruptions which are "unplanned events that may occur in the supply chain which might affect the normal or expected flow of materials and components" (Svensson, 2002). A political disruption that could take place at one point in the chain can adversely affect the performance of one or more elements located elsewhere in the supply chain. It can affect the normal flow of goods and materials within a supply chain (Chui et al., 2007; Melnyk et al., 2009).

Textile and apparel production are time-consuming, though with a high-profit margin (Thompson and Thompson, 2014). Pakistan is among the cheapest textile production countries and has the capacity to provide all kind of textile goods 
from house wear to industrial clothing. The issues it faces in the efficiency and reliability of its supply chain network. However, it is becoming difficult for Pakistan to continue providing cheap textile products. Compared to regional competitors (i.e. China, India and Bangladesh), Pakistan faces different, and more serious problems like terrorism and political disruptions (Daily Times, 2014). Respondents raised concern on spending exorbitant amount of resources on the war against terrorism rather than on economic reconstruction and employment generation. It requires massive improvements to supply chain networks to reduce the chances of disruptions (Yusuf, 2014).

\subsection{Production planning and execution}

Production planning and execution are seen important to the efficiency of textile supply chain. Textile manufacturing typically consists of a series of interconnected value-added nodes. If any of the processes is delayed or disturbed, it affects the performance of the entire supply chain. Although, Pakistani textile manufacturers have started to use latest technology and computerized machines but there is still no proper production planning and systems put in place to mitigate the threats from political disruptions. Production planning is performed by staff who often have no formal training, yet they manage to attain senior positions based on years of experience. This is also due to the lack of workplace based training and professional development opportunities. Cost saving is found to be the key factor in recruiting training staff to undertake production planning and execution. This situation often leads to industrial action and labor strikes. Textile manufacturers are required to plan their production strategy and execute as per the order requirements. But in Pakistan, unstable political conditions make it harder to plan and execute within the schedule and at the projected cost. Change of government and the resultant prohibitive regulations is also affecting firms' ability to improve production planning when the manager of a textile spinning manufacturing firm stated: "With frequent changes in government and their policies are hindering us to plan and prepare for further improvements in the manufacturing system. This includes installation of testing and quality control system that required government permission to import" (FBA).

Planning and execution are also important with growing competition while serving the international market. Manufacturers should plan and maintain their production by better planning, scheduling and goal settings. For this, they need to know what kind of problems they would confront if they are operating in disrupted political conditions. On the one hand, supply and demand uncertainty inflicted by the unstable political environment may reduce investment and the rate of textile business growth. On the other hand, ineffective planning and execution may lead to longer delivery lead time which reduces the ability of firms to compete in a globalized market. Political disruption is seen as a business risk when the interviewee of a garment manufacturer firm stated: "We consider political disruption as a high-risk factor while preparing for any new order or new product manufacturing because. Political disruptions are causing late delivery of raw material and also responsible of production delays due to labor shortages because of strikes and sit-ins." (MH).

Stable political conditions are paramount to an effective production planning, scheduling and order-fulfilment. This link was less clearly known in the supply chain management literature. With unstable political conditions, textile manufacturers may face raw material shortages that may lead to production uncertainty.

\subsection{Delivery lead time issues}

Delivery lead-time issues as highlighted by interviewees are directly affected by externally led politically motivated disruptions of supply network. Textile supply chains are more vulnerable to disruptions when the lead time is longer. Delivery lead time starts with an order placement and the final delivery of products to the customer. The textile industry is more prone to longer delivery lead time because of longer and complex manufacturing processes, higher chances of production delay, raw materials procurement and frequent machine shutdown. This less resilient textile supply chain is easily affected by political disruption. This is attested by the Manager of a textile apparel manufacturing firm when it is stated; "Pakistan is having big problems in the political system and getting serious because of clashes between parties to get in power, and this situation affects us to maintain production operations. Production and on-time delivery based on the external political conditions and internal manufacturing planning." (MK).

In today's customer-centric market, manufacturers and retailers are expected to respond to shorter lead time by any possible way to fulfil Just-in-Time demand. One way to improve delivery lead is by improving the supply chain agility and to effectively manage potential disruptions in their supply chains. Majority of the participants are of the view that the delivery lead-time in the textile industry is shortened. The competitiveness of Pakistan as a global supplier of textile has drastically reduced due to production inflexibility and reliability of the distribution network. One Hosiery manufacturer expressed this view; "Delays in production is the main issue that we are facing at the moment due to governments nonserious behavior towards handling textile industry problems totally disappointing for us. Government fails to provide proper infrastructure for the export of textile goods from dry port to main port and from port to the world." (UA).

Terrorist attacks, political violence, political strikes and transportation delays are causing longer delivery lead-time in Pakistan. Textile manufacturers require raw materials from different parts of the country to maintain and maximize production capacity, yet due to unstable political conditions, they are mostly unable to meet the expected delivery leadtime thresholds. Countries that are politically stable spend more resources to train staff to resist against external disruptions or changes enforced by non-state or non-political agencies (Bueno de Mesquita et al., 2014). Some active 
non-state agents, like terrorist groups, are actively engage in political and supply chain disruptions. These groups are trying to change the legal structure of the country. They are also more likely to contribute to the country's political and economic instability, with the government spending more of its budget on security rather than education, social and business activities (Cordesman et al., 2011). These politically disruptive events are the major cause of long delivery leadtime in Pakistan's textile supply chain.

\subsection{Impact on supply chain performance}

Political stability is not only important for nation building and survival of any nation but also a key factor of industrial growth, economic development and supply chain performance. Pakistan is struggling to protect the political systems and sustain democracy in the post-colonial period. Wider impacts of political instability are attested by interviewees when they identify and establish the likely relationship between political disruptions and supply chain performance. The political protests by the opposition parties, unions, and the government are common mechanisms to exhibit power and authority. Long march, road blockage, businesses shut down and protest are commonly used tactics to draw attention and extend global reach. Consequently, supply networks for all kinds of textile manufacturing are negatively impacted. Textile manufacturers were out of workers and raw materials during this period of disruption, which is stated by a participant of a textile apparel manufacturer firms as: "Political disruption badly affects our supply chain network because strikes and political conflicts delaying our production as well as delivery of goods. These disruptions also effect on customer's business activities in result they can move to other countries for their supplies" (MK).

Pakistan is surrounded by more stable political systems such as India and China, which provide more informed strategies and development plans for businesses to grow and compete in the global marketplace. A senior Manager of Pakistan Hosiery Manufacturers and Export Association expressed his disappointment with public service provisions by stating; "More than RS200 billion of the export rebate, sales tax refund etc. of the textile industry is stuck up with the government, and they are compelled to buy electricity and gas at rates most expensive compared to other countries in the region".

Stability in a political system facilitates manufacturers to grow businesses, but unstable political system creates several business issues including a lack of investment, relocation of businesses to other countries, offshoring and huge economic losses. There are concerns reflected by many interviewees on failure of public services and the urgent need for government to revisit current economic development policies and introduce new strategic plans to improve law and order situation, provide security to business community and build infrastructure for businesses to access the international market. The detrimental impacts of political disruptions on supply chain performance are found to be incremental and severe as attested by the Mill manager of a textile spinning firm: "Terrorism, political strikes and targeted violence are causing the delays in supply chain operations. These events mostly caused huge loses to the manufacturers because of late delivery of readyto-deliver goods." (MM).

In Pakistan, the textile industry is vertically and horizontally integrated. Textile manufacturers require raw materials from different manufacturers who are located in different parts of Pakistan. For example, textile yarn manufacturers require cotton bales from ginning, and ginning mills are often geographically separated from spinning facilities. This spatial mismatch is subject to different levels of political disruptions, which vary across different provinces in Pakistan. One textile hosiery manufacturing industry interviewee reflected his view on operational challenges in operating in a geographically fragmented market to serve the international market. "We are manufacturing for international firms and disruptions in our operations can badly impact that's the reason why we are concerned about supply chain performance." (UA).

Finding of this study makes a compelling argument to develop supply chain mitigation strategies to tackle the challenges associated with political disruptions which are crippling Pakistan's economy, weakening supply chains and reducing the competitiveness of the textile industry. Internal and external sources to the supply chain including natural disasters, transport failure, labor dispute, terrorism and political disruptions are all causes of supply chain disruptions. These events have created different levels of disruption in the supply chain along the entire spectrum from upstream to downstream stages.

\subsection{A synthesis}

The key findings are synthesized to frame a new model of vicious cycle to illustrate the interactions and interdependencies between political disruptions and supply chain performance. Political disruptions are either internally or externally driven. The external disruptions such as political violence, political strikes, corruptions, riots and street demonstrations, terrorism, political assassinations, energy crises and natural disasters. While the internal disruptions include labor union strikes, machine breakdown, employee and employer relation, production delay raw material quality and delivery. The impact of several disruptions in textile supply chain further categories into four different types according to their impacts on supply chain performance from low to high. These categories include: i) external to external, ii) external to internal, iii) internal to external, and iv) internal to internal.

The vicious cycle, as shown in figure 5, is drawn to illustrate the compounded impact of political disruptions on supply 
chain performance of Pakistan's textile industry. For instance, political strike is a form of political disruption, initiating delays in transportation, leading to further delay in production, affecting on delivery lead-time and, resulting in poor supply chain performance. At this point, supply chain performance needs to be improved by breaking the cycle from vicious to virtuous. These convoluted relationships are identified by the supply chain manager of a spinning firm when he noted: "Most of the disruptions we are facing in daily operations directly or indirectly because of current political system such as delivery of raw material or even labor shortages are because of political gatherings or strikes resultant effects on the delivery lead time." (FBA).

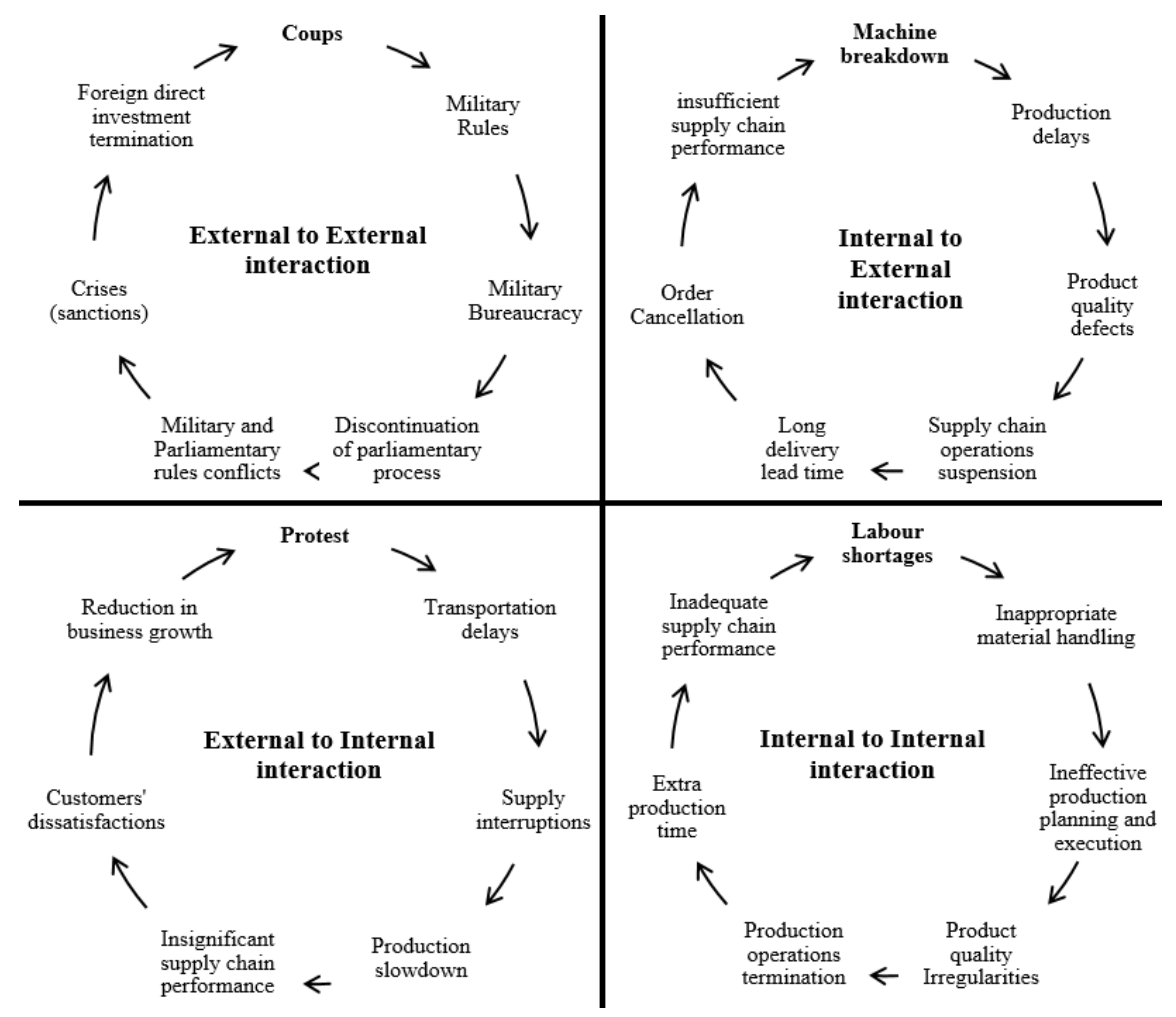

Figure 5. Vicious cycle of political disruptions and supply chain performance

This two-dimensional mapping of views and opinions of respondents reflect the latent patterns that capture the complex interactions between political disruptions and supply chain disruptions. Among them are those which emanate from the external environment but exert minimum effect on external operations yet having maximum impact on internal operations. For example, transportation disruptions occur because of street protests, which in turn cause raw material supply interruption. These interconnected disruptions increase the chance of compounded and cascading effect of supply chain performance. The impact of these disruptions is like be the 'bull-whip effect' whereby a small change in a system tends to have big impact on a large supply scale with national or global significance.

External supply chain disruptions have an impact on external as well as internal operations. Not only do these types of disruption completely thwart the external logistics operations and break-down of supply chain network; they also tend to have flow-on effects on internal production operations. One textile hosiery mill manager expressed this view by stating: "Textile production operations rely on external supply chain activities. Raw material supply, labor movement and the transportation of finished goods may be disturbed because of external supply chain disruptions. These disruptions affect production operations for a long time after the delay in the supply of raw materials and the delivery of finished goods has been resolved." (UA).

The impact of internal disruptions (from inside the production unit) on external supply chain operations is relatively less severe (Chiang et al., 2012). That is, if one production facility shuts down or ceases operations, then the buyer begins to search for opportunity to move on to the next production facility to sustain its supply operations. Textile manufacturing operations are complex and highly dependent on the effectiveness of inter-firm collaboration and supply coordination. Textile product manufacturing involves the use of multiple machines e.g. the spinning process alone involves blow room processing, carding, drafting, warping, and the use of spinning frames, winding, and packaging. There is a high possibility that interruptions may occur during the production process, considering the material handling by the workers. Material handling requires certain skills to upload and install materials from one machine to next. Mishandling affects the production process. Politically motivated disruptions in one of these functions influence the entire production cycle. As one textile spinning mill manager noted: "Disruptions are unexpected events in textile industries. Because of these, production performance is reduced and there are more likely to be defects in the final product. Internal textile operations 
are complicated because every process relies on the previous one. These processes are all part of a chain. A stoppage or delay in one process will affect the whole chain." (MM).

Unexpected disruptions in production operations create serious challenges for manufacturers. Machine break-down, building fires, and labor strikes are the most common internal disruptions, which can delay or cease internal production operations. Some of these are politically motivated or are related to industrial disputes. Textile production disruptions that impact directly on the internal supply chain also impact indirectly on external supply chain performance. A production disruption leads to several other internal production problems; these include long-delivery lead time, order cancelation, and risk to the retailer's business.

Internal textile production operations are relatively more vulnerable to disruptions due to complicated production operations and functional interdependencies. Defects in relation to machine settings, machine maintenance, raw material conditioning and raw material delivery from one machine to another create common disruptions causing the production delays. These labor-intensive functions are highly vulnerable to disruptions that emerge from industrial disputes or labor politics. Textile supply chain managers are not only responsible for managing supply chain but also the disruptions related to the deployment of labor. With reference to the effects of internal disruptions on external supply chain operations, one dyeing and processing mill manager highlighted the seriousness of this issue by stating: "The textile internal environment is extremely vulnerable to disruptions due to its complicated production operations. These operations are linked to each other, and disruption in one part of the production process will impact on the entire operations. Internal disruptions are more costly for the textile dyeing due to the use of extensive quality chemicals." (US).

Internal textile production operations are important for gaining trust of customers and uplifting confidence in market. Timely delivery is critical to this trust and to the reliability of supply chain. Disruptions increases the delivery lead-time that will, in turn, affect the supply chain performance of the textile organization. New markets in a globalized marketplace can be tapped if supply chain performs at a high standard with higher level of reliability and certainty.

The interpretation of the interview data indicates that external political disruptions have a much wider impact on external supply chain operations than they do on internal processes within the textile organization. These disruptions can slow down or in some cases cease external supply chain operations such as procurement of materials and distribution of finished goods to markets. The most common forms of external supply chain disruptions are political strikes, political violence, terrorism and social disorder. Political disorders increase the chance of civil disobedience and security risks for both manufacturers and supply chain operators. Such risks further increase the chances of supply chain disruptions, leading to financial losses for manufacturers and reduced supply chain performance. External disruptions, as shown in Figure 5, tend to have intense impact on both internal and external supply chain operations. But their impact on external operations is more pronounced. This is partly because the firms have less control over external factors; while internal process are easy to control and manage. For example, reliable and secured supply of raw materials are essential to perform production operations, but they are highly vulnerable to external perturbations.

There is evidence that suggests internal textile operational disruptions are the result of mishandling of operational issues by the management. For example, ineffective production scheduling causes production planning failures, poor production performance, and increased supply risk. Anachronistic technology and machine breakdowns are common ground for health and safety of workers, which in turn could lead to industrial action. Internal operational disruptions might not necessarily stop external supply chain operations, but they can certainly make it less efficient. Customers in the globalized marketplace have the choice to procure goods from other manufacturers to fulfil their requirements to operate production systems. Disruptions caused by internal processes are recognized by the interviewee from a Union Leader when he expressed his view: "Internal textile supply chain operations are more complicated, but easy to manage. All these operations involve workers and managers responsible for their allocated roles or jobs. The impact of internal disruptions on the internal environment is greater than the impact of internal disruptions on external supply chain operations. Internally, production operations can become disturbed due to technological failure, human-made mistakes, or raw material moisture issues. All of these problems can reduce our production efficiency.” (HM).

Furthermore, internal operational disruptions have a direct and significant impact on the external environment when customers rely on one supplier and unwilling or unable to source a different supplier. In the globalized economy, textile customers require products that are tailored to customer demand; this should take into account the specific raw materials requirements, designs, and color combination. Within the external environment, it is difficult to satisfy a customer's demand in case of (primary) supply failure or an occurrence of an unexpected disruption. Consequently, the management of internal production operations is important for reducing the likelihood of disruptions. Interviewees also highlighted that the majority of textile manufacturing firms have established hard and soft systems to manage unexpected internal disruptions; these include proper machine overhauling, production scheduling adjustment and training of labor force. Such systems help mitigate the impact of potential disruptions in their production operations and distribution networks.

External textile supply chain operations rely on agents who are outside the direct influence of textile manufacturers. These agents are independent third parties who provide services to manufacturers and retailers. They are responsible for all kinds of external supply chain operations, from raw materials procurement to delivering of finished goods. Interviewees recognized that there are only a few textile organizations that have their own supply chain service providers in Pakistan. Others have limited capabilities to vertically integrate their supply chain. Most of them are small to medium sized organizations, which are relatively more vulnerable to political disruptions. These firms are therefore at a greater 
risk of experiencing disruptions because of a labor strike, a change in the political regime, terrorism, natural disasters, conflicts between different ethnic groups, system failure such as planned and unplanned load shedding, fire incidents (arsons and accidents), malfunctions of information technology, and oil crises. Internal supply chain disruptions occur despite the controlled production environment. These disruptions are both the causes and consequences as they are intertwined with internal and external forces such as machine breakdown, import or export restrictions (sanctions), delivery delays, transport failure, increasing customs duties and tariffs, an abrupt change in customer demand, market failure (increasing raw material prices, labor shortages), and inventory disruptions. However, both types of disruptions have a combined and individual impact on supply chain operations. In many cases, as argued by respondents, it is difficult to detect the source of a disruption, which may be located inside or outside the supply chain systems. The interpretation of interview data shows that textile supply chain operations are becoming more complex and vulnerable to disruptions; this is on account of shorter textile product fashion cycles. Textile production consists of interconnected processes, which involve different tasks to complete a production cycle.

The findings of this study provide empirical evidence to support the argument that political disruptions are directly and indirectly impacting on supply chain performance. The impact of political disruptions varies across different parts of supply chain and these impacts are interwoven with internal and external processes and institutional structures. These political disruptions have interrupted the material flows, disrupted the production operations and caused production delays. A stable, predictable political regime and an effective regulatory environment are demanded by the textile industry in Pakistan to enhance their ability to compete against other competitors in the international markets through building business strategies and convivial regulatory environment to support businesses and improve supply chain performance.

\section{Conclusion}

This paper has explored the complex and intertwined relationships between political disruptions and supply chain performance in Pakistan. The findings suggest that political disruptions often do not directly impact on supply chain performance. However, their impact is mediated through supply chain disruptions. The impacts, however, are wider, complex and convoluted. Political disruptions, regardless of its size and scale, tend to cause large scale supply chains disruptions with long-term impacts. This might suggest the impact like a 'bull-whip effect', which cascades down from the initial ginning stage, through to garments/apparel manufacturing and through to distribution of textile to end customers. The complexity of this relationships is illustrated by a vicious circle that connects different disruption nodes across the textile supply chain. Political disruptions are therefore more likely to cause ripple effects in the supply chain whereby coordination and collaboration such as longer lead-time, production delay, rescheduling, transportation delays, and facility production shutdown are severely affected.

\section{References}

Aisen, A., Veiga, F.J., 2013. How does political instability affect economic growth? European Journal of Political Economy 29, 151167.

Alex, S., Jongman, A., 2005. Political Terrorism. A New Guide to Actors, Authors, Concepts, Data Bases, Theories and Literature. Transaction Publishers, London.

Awokuse, T.O., Gempesaw II, C.M., 2005. Foreign political instability and US agricultural exports: Evidence from panel data. Economics Bulletin 6, 1-12

Bashir, M.F., Xu, C., Zaman, K., Akhmat, G., Ikram, M., 2013. Impact of foreign political instability on Chinese exports. Economic Modelling 33, 802-807.

BCI Company, 2015. Definitive ranking of supply chain resilience around the world. <http://www.thebci.org/index.php/about/newsroom\#/news/definitive-ranking-of-supply-chain-resilience-around-the-world-112339>.

Beamon, B.M., 1999. Measuring supply chain performance. International Journal of Operations \& Production Management 19, $275-$ 292.

Blackhurst, J., Craighead, C.W., Elkins, D., Handfield, R.B., 2005. An empirically derived agenda of critical research issues for managing supply-chain disruptions. International Journal of Production Research 43, 4067-4081.

Brenner, V., 2015. Causes of Supply Chain Disruptions: An Empirical Analysis in Cold Chains for Food and Pharmaceuticals. Springer Gabler. Wiesbaden.

Bueno de Mesquita, E., Fair, C.C., Jordan, J., Rais, R.B., Shapiro, J.N., 2015. Measuring political violence in Pakistan: Insights from the BFRS Dataset. Conflict Management and Peace Science 32, 536-558.

Butkiewicz, J.L., Yanikkaya, H., 2005. The impact of sociopolitical instability on economic growth: Analysis and implications. Journal of Policy Modeling 27, 629-645.

Business Insider Australia, 2014. This Map Reveals Which Countries Are Most Likely to See Political Violence In 2015. <http://www.businessinsider.com.au/map-shows-risks-of-political-violence-in-2015-2014-12?r=US\&IR=T>.

Casey, N., Pasztor, A., 2007. Safety agency, mattel clash over disclosures. Wall Street Journal A1.

Chiang, C.Y., Kocabasoglu-Hillmer, C., Suresh, N., 2012. An empirical investigation of the impact of strategic sourcing and flexibility on firm's supply chain agility. International Journal of Operations \& Production Management 32, 49-78.

Chui, A.C., Lloyd, A.E., Kwok, C.C., 2002. The determination of capital structure: Is national culture a missing piece to the puzzle? 
Journal of International Business Studies 33, 99-127.

Cordesman, A.H., Burke, A.A., Vira, V., 2011. Pakistan: Violence vs. Stability. Center for Strategic and International Studies, Washington DC.

Craighead, C.W., Blackhurst, J., Rungtusanatham, M.J., Handfield, R.B., 2007. The severity of supply chain disruptions: Design characteristics and mitigation capabilities. Decision Sciences 38, 131-156.

DAWN, 2016. Political instability and economy. <http://www.dawn.com/news/1291420>.

Daily Times, 2014. Socio-economic impact of terrorism on Pakistan. <http://www.dailytimes.com.pk/business/21-Dec-2014/socioeconomic-impact-of-terrorism-on-pakistan>.

Davarzani, H., Zanjirani Farahani, R., Rahmandad, H., 2015. Understanding econo-political risks: Impact of sanctions on an automotive supply chain. International Journal of Operations \& Production Management 35, 1567-1591.

Dweekat, A.J., Hwang, G., Park, J., 2017. A supply chain performance measurement approach using the internet of things: Toward more practical SCPMS. Industrial Management \& Data Systems 117, 267-286.

Feng, Y., 2001. Political freedom, political instability, and policy uncertainty: A study of political institutions and private investment in developing countries. International Studies Quarterly 45, 271-294.

Fosu, A.K., 2003. Political instability and export performance in sub-Saharan Africa. Journal of Development Studies 39, 68-83.

Gandhi, A.V., Shaikh, A., Sheorey, P.A., 2017. Impact of supply chain management practices on firm performance: Empirical evidence from a developing country. International Journal of Retail \& Distribution Management 45, 366-384.

GEO News, 2016. Changing political realities in Pakistan. <https://www.geo.tv/latest/116120-Changing-political-realities-inPakistan>.

Harvard Business Review, 2014. From Superstorms to Factory Fires: Managing Unpredictable Supply-Chain Disruptions. <http://hbr.o rg/2014/01/from-superstorms-to-factory-fires-managing-unpredictable-supply-chain-disruptions/ar/1>.

Hendricks, K.B., Singhal, V.R., 2012. Supply Chain Disruptions and Corporate Performance. In: Mehrotra, A., Gurnani, H., Ray, S. (Eds), Supply Chain Disruptions. Springer, London.

Herald, 2014. Politics of Disruptions. <http://herald.dawn.com/2014/11/18/politics-of-disruption-2.html>.

Hopp, W.J., Iravani, S.M., Liu, Z., 2012. Mitigating the Impact of Disruptions in Supply Chains. In: Mehrotra, A., Gurnani, H., Ray, S. (Eds), Supply Chain Disruptions. Springer, London.

Jalal, A., 2014. The Struggle for Pakistan. A Muslim Homeland and Global Politics. The Belknap Press of Harvard University Press, London.

Jongman, A.J., 2017. Political Terrorism: A New Guide to Actors, Authors, Concepts, Data Bases, Theories, and Literature. Transaction Publishers, London.

Khan, A.A., Khan, M., 2010. Pakistan textile industry facing new challenges. Research Journal of International Studies 14, 21-29.

Khan, S.U., Saqib, O.F., 2011. Political instability and inflation in Pakistan. Journal of Asian Economics 22, 540-549.

Kobrin, S.J., 1977. The Conditions under Which Political Disruption Results in Increased Political Risk. Massachusetts Institute of Technology, Massachusetts.

Koprulu, A., Albayrakoglu, M.M., 2007. Supply chain management in the textile industry: A supplier selection model with the analytical hierarchy process. Proceeding of the International Symposium on the Analytic Hierarchy Process (ISAHP) 2007, Vina Del Mar, Chile.

Langley Jr., C.J., 2012. 2013 Third-Party Logistics Study: The State of Logistics Outsourcing. Capgemini, Paris.

Lee, B.X., 2016. Causes and cures VI: The political science and economics of violence. Aggression and Violent Behavior 28, 103-108.

Lee, C.C., Lin, C.W., 2016. Globalization, political institutions, financial liberalization, and performance of the insurance industry. The North American Journal of Economics and Finance 36, 244-266.

Lorentz, H., Hilmola, O.P., 2012. Confidence and supply chain disruptions: Insights into managerial decision-making from the perspective of policy. Journal of Modelling in Management 7, 328-356.

Melnyk, S.A., Rodrigues, A., Ragatz, G.L., 2009. Using Simulation to Investigate Supply Chain Disruptions. In: Zsidisin, George A., Ritchie, Bob (Eds), Supply Chain Risk. Springer, Boston.

Musa, S.N., 2012. Supply chain risk management: Identification, evaluation and mitigation techniques. Doctoral dissertation, Linköping University, Sweden.

Nawaz, A., 2015. Political instability in Pakistan (1947 1956). International Journal of Art \& Humanity Science 2, 19-21.

New Era Publication Corporation, 2015. Political Stability vs Economic Development. <https://www.newera.com.na/2015/03/13/politi cal-stability-economic-development/>.

Pakistan \& Gulf Economist, 2018. Pakistan's Textile Industry: Challenges and Opportunities. <http://www.parkistaneconomist.com/2 018/10/22/pakistans-textile-industry-challenges-and-opportunities/>.

Patton, M.Q., 2002. Qualitative Research and Evaluation Method. Sage, Thousand Oaks.

SATP, 2019. Fatalities in Terrorist Violence in Pakistan 2003-2019. <http://www.satp.org/satporgtp/countries/pakistan/database/casua lties.htm>.

Schoenherr, T., Tummala, V.R., Harrison, T.P., 2008. Assessing supply chain risks with the analytic hierarchy process: Providing decision support for the offshoring decision by a US manufacturing company. Journal of Purchasing and Supply Management $14,100-111$.

Sheffi, Y., 2005. The Resilient Enterprise: Overcoming Vulnerability for Competitive Advantage. MIT Press, Cambridge.

Svensson, G., 2002. A conceptual framework of vulnerability in firms' inbound and outbound logistics flows. International Journal of Physical Distribution \& Logistics Management 32, 110-134.

Tahir, S.H., Ali, Y.I., Hanan, A., 2014. Impact of direct and indirect tax incentives on textile industry (Pakistan). Euro-Asian Journal of Economics and Finance 2, 21-27.

Tang, O., Musa, S.N., 2011. Identifying risk issues and research advancements in supply chain risk management. International Journal of Production Economics 133, 25-34.

The Express TRIBUNE, 2004. Measuring effects: Sit-ins paralyse Islamabad, slow down progress. <http://tribune.com.pk/story/75921 2/sit-ins-paralyse-islamabad-slow-down-progress/>. 
Do political disruptions affect supply chain performance? A qualitative case study of the textile supply chain in Pakistan

The World Bank, 2014. Pakistan Development Update: Economy Gradually Improving. <https://www.worldbank.org/en/news/feature/ 2014/04/09/pakistan-dvelopment-update-economy-gradually-improving>.

Thompson, R., Thompson, M., 2014. Manufacturing Processes for Textile and Fashion Design Professionals. Thames \& Hudson, New York.

TRIBUNE News, 2013. Statistics on textile industry in Pakistan. <http://tribune.com.pk/story/522292/statistics-on-textile-industry-inpakistan/>.

Wang, N., Fang, X., Gou, Q., Liang, L., 2017. Supply chain performance under pull or push contracts in the presence of a market disruption. International Transactions in Operational Research 24, 713-736.

Wilson, K., Barbat, V., 2015. The supply chain manager as political-entrepreneur? Industrial Marketing Management 49, 67-79.

World Bank Cross-Country Data, 2015. Pakistan: Political Stability and Absence of Violence/Terrorism: Estimate. World Bank, Washington DC.

Yusuf, M., 2014. Pakistan's Counterterrorism Challenge. Georgetown University Press, Washington DC.

Zsidisin, G.A., Ragatz, G.L., Melnyk, S.A., 2005. The dark side of supply chain management. Supply Chain Management Review 9 , 46-52. 